\title{
PROFIL PERIKANAN TUNA DAN CAKALANG DI INDONESIA
}

\section{The Profile of Tuna and Cakalang Fishery in Indonesia}

\author{
Maulana Firdaus \\ Balai Besar Riset Sosial Ekonomi Kelautan dan Perikanan \\ Gedung BRSDMKP I Lt. 4 \\ Jalan Pasir Putih Nomor 1 Ancol Timur, Jakarta Utara \\ Telp: (021) 64711583 Fax: 64700924 \\ *email: mr_firda@hotmail.com \\ Diterima tanggal: 13 Februari 2018 Diterima setelah perbaikan: 9 Maret 2018 \\ Disetujui terbit: 7 Juni 2018
}

\begin{abstract}
ABSTRAK
Indonesia memegang peranan penting dalam perikanan Tuna, Tongkol dan Cakalang di dunia. Indonesia telah memasok lebih dari $16 \%$ produksi Tuna, Tongkol dan cakalang dunia. Tuna dan cakalang memiliki peranan penting bagi sektor perikanan tangkap di Indonesia sehingga pengetahuan tentang profil perikanan Tuna dan cakalang menjadi sangat penting untuk diketahui. Kajian yang dilakukan pada tahun 2017 ini bertujuan untuk mendeskripsikan profil perikanan Tuna dan cakalang di Indonesia yang akan dikemukakan berdasarkan penelurusan data sekunder berupa data statistik, laporan penelitian dan publikasi ilmiah terkait perikanan Tuna dan cakalang di Indonesia yang dianalisis secara deskriptif. Hasil kajian menunjukkan bahwa perikanan Tuna dan cakalang di Indonesia terdiri jenis yaitu industri dan artisanal. Daerah penyebaran ikan Tuna dan cakalang meliputi Laut Banda, Laut Maluku, Laut Flores, Laut Sulawesi, Laut Hindia, Laut Halmahera, perairan utara Aceh, barat Sumatera, selatan Jawa, utara Sulawesi, Teluk Tomini, Teluk Cendrawasih dan Laut Arafura. Produksi Tuna dan cakalang terus meningkat sejak tahun 2000 sampai dengan tahun 2015. Peningkatan produksi Tuna dan cakalang menunjukkan bahwa tingginya tingkat permintaan terhadap kedua komoditas tersebut. Alat tangkap yang digunakan untuk menangkap Tuna dan cakalang sangat beragam yang dapat dikelompokkan menjadi 6 jenis, yaitu rawai Tuna (Tuna long line), rawai hanyut selain rawai Tuna (drift longline other than Tuna long line), rawai tetap (set long line), huhate (skipjack pole and line), pancing tonda (troll line) dan pancing yang lain (other pole and line).
\end{abstract}

Kata Kunci: perikanan; tuna; cakalang; Indonesia

\begin{abstract}
Indonesia plays an important role in Tuna and Skipjack fisheries in the world due to its supply of more than $16 \%$ of the world's Tuna and skipjack production. Since they have been being a vital commodity in capture fisheries in Indonesia, it is important to have knowledge of Tuna and skipjack fisheries. This study was conducted in 2017 and it aims to describe the profile of Tuna and skipjack in Indonesia that built upon secondary data. The data were collected from statistical data, scientific report and publication related to Tuna and skipjack fisheries in Indonesia and they were analyzed using descriptive method. The results suggest that Tuna and skipjack fisheries in Indonesia consist of industrial and artisanal types. The fishing ground of Tuna and skipjack covering Banda Sea, Maluku Sea, Flores Sea, Sulawesi Sea, Indian Ocean, Halmahera Sea, Northern Aceh Sea, West Sumatra, South Java, North Sulawesi, Tomini Bay, Cendrawasih Bay and Arafura Sea. The production of Tuna and skipjack Tuna continues to increase particularly during 2000 to 2015. The increased number of Tuna and skipjack production indicates the high demand of these two commodities. There are various fishing gear to catch Tuna and Skipjack, which can be grouped into 6 types, namely Tuna long line, drift longline other than Tuna long line, set long line, huhate (skipjack pole and line), troll line and other fishing rods (other pole and line).
\end{abstract}

\section{Keywords: fisheries; tuna fish; skipjack Indonesia}




\section{PENDAHULUAN}

Sumber daya kelautan dan perlkanan merupakan salah satu potensi sumber daya alam yang sangat besar dan mendapatkan perhatian yang serius di Indonesia. Secara singkat, dua per tiga wilayah Indonesia terdiri dari laut, memiliki pulau sebanyak lebih dari 17.000 serta garis pantai sepanjang $81.000 \mathrm{~km}$. Pada Rencana Pembangunan Jangka Menengah Nasional (RPJMN) tahun 2015-2019 menekankan bahwa fokus terbesar diberlkan pada bidang kelautan yang di dalamnya adalah perlkanan dengan cara mengoptimalkan pemanfaatan sumber kekayaan laut secara berkelanjutan (Bappenas, 2014). Selama ini sektor perlkanan dianggap telah teruji sebagai sektor yang mampu bertahan dalam situasi krisis, baik ekonomi, finansial maupun moneter serta mampu menyediakan bahan pangan penting bagi masyarakat, sumber pendapatan serta sekaligus menyerap tenaga kerja dalam jumlah yang cukup signiflkan.

Sektor perlkanan memiliki kontribusi yang besar terhadap pertumbuhan ekonomi di beberapa negara maju seperti Amerika Serikat, Jepang, China dan negara-negara Eropa. Hal ini dipertegas oleh pernyataan Fauzi (2010) bahwa sektor perlkanan dibeberapa negara di dunia telah menjadi sumber "energi" pertumbuhan ekonomi dan juga menjadi "mesin pertumbuhan" ekonomi regional. Hal ini pun terjadi di Indonesia, dimana sektor perlkanan terus memberlkan peningkatan kontribusi terhadap pertumbuhan ekonomi sehingga pemerintah memberlkan perhatian lebih. Perhatian tersebut diimplementaslkan melalui dukungan kebijakan fiskal dan non fiskal yang bertujuan untuk meningkatkan kesejahteraan rakyat, terutama nelayan (Samosir, 2014). Hal tersebut menegaskan bahwa sumber daya perlkanan adalah aset penting negara yang jika dikelola dengan baik akan memberlkan manfaat yang maksimum bagi masyarakat ( Fauzi dan Anna, 2002).

Salah satu jenis sumber daya lkan yang memiliki potensi besar di Indonesia adalah dari kelompok Ikan pelagis besar antaranya adalah Tuna, Tongkol dan Cakalang. Indonesia memegang peranan penting dalam perlkanan
Tuna, Tongkol dan Cakalang di dunia. Pada tahun 2011 produksi Tuna, Tongkol dan Cakalang dunia sebesar 6,8 juta ton dan meningkat menjadi lebih dari 7 juta ton pada tahun 2012 dengan rata-rata produksi Tuna, Tongkol dan Cakalang periode tahun 2005-2012 sebesar 1.033.211 ton (KKP, 2015). Indonesia telah memasok lebih dari $16 \%$ produksi Tuna, Tongkol dan Cakalang dunia. Pada tahun 2013, volume ekspor Tuna, Tongkol dan Cakalang mencapai sekitar 209410 ton dengan nilai USD 764,8 juta (KKP, 2014). Disamping itu, Indonesia juga merupakan negara kontributor produksi terbesar diantara 32 negara anggota Indian Ocean Tuna Commission (IOTC) dengan rata-rata produksi tahun 2009 - 2012 sebesar 356.862 ton per tahun ( KKP, 2015).

Sumber daya Ikan Tuna dan Cakalang memiliki peranan penting bagi sektor perlkanan tangkap di Indonesia. Pengetahuan tentang profil perlkanan Tuna dan Cakalang di Indonesia menjadi sangat penting untuk diketahui. Tujuan penulisan ini yaitu untuk mengetahui profil perlkanan Tuna dan Cakalang di Indonesia yang akan dikemukakan berdasarkan penelurusan data sekunder berupa data statistik, laporan penelitian dan publikasi ilmiah terkait perlkanan Tuna dan Cakalang di Indonesia. Kajian ini telah dilakukan pada tahun 2017. Analisis data pada kajian ini dilakukan secara deskriptif sehingga dapat ditarik sebuah kesimpulan terhadap objek yang dikaji.

\section{Sentra Tuna dan Cakalang di Indonesia}

Tuna dan spesies Ikan pelagis besar lainnya pada umumnya merupakan Ikan yang beruaya jauh (highly migratory fish) atau berada di wilayah Zona Ekonomi Ekslusif dari suatu atau lebih negara dan laut lepas, maka pengelolaanya harus dilakukan melalui kerjasama regional dan atau internasional. Pasal 10 ayat (2) UndangUndang Nomor 31 Tahun 2004 tentang Perlkanan sebagaimana telah diubah dengan UndangUndang Nomor 45 Tahun 2009 disebutkan bahwa pemerintah ikut serta secara aktif dalam keanggotaan badan/lembaga/organisasi regional dan internasional. Selanjutnya, pemerintah juga telah menerbitkan Undang-Undang Nomor 12 Tahun 2009 tentang Pengesahan Agreement 
for the Implementation of the Provisions of the United Nations Conventions on the Law of the Sea of 10 December 1982 Relating to the Conservation and Management of Straddling Fish Stock and Highly Migratory Fish Stock (United Nation Implementing Agreement - UNIA 1995). Pengesahan UNIA 1995 merupakan komitmen Indonesia untuk bekerjasama dengan berbagai negara di dunia dalam rangka pengelolaan Tuna yang berkelanjutan. Pengelompokkan sumber daya Ikan Tuna dan Cakalang dapat dilihat pada Tabel 1.

Sumber daya Ikan Tuna dan Cakalang memiliki nilai ekonomis penting dan banyak tersebar hampir di seluruh wilayah perairan Indonesia. Nilai ekonomis yang dimiliki Ikan Tuna dan Cakalang menjadlkannya sebagai komoditas utama dari sub sektor perlkanan. Ikan Tuna dan Cakalang merupakan bagian dari Ikan pelagis besar yang memiliki karakteristik oseanik atau memiliki sifat selalu beruaya dari suatu perairan ke perairan lain yang mempunyai kondisi oseanografi, biologis dan meteorologis yang sesuai dengan habitatnya (Sibagariang et al., 2011). Tuna dan Cakalang merupakan komoditas ekspor penting di Indonesia. Daerah penangkapannya tersebar mulai dari kawasan barat sampai dengan timur Indonesia. Kawasan barat meliputi wilayah pengelolaan perlkanan Samudera Hindia dan untuk kawasan timur meliputi wilayah pengelolaan perlkanan Selat Makasar dan Laut Flores, wilayah pengelolaan perlkanan Laut Banda, wilayah pengelolaan perlkanan Laut Maluku dan wilayah pengelolaan perlkanan Sulawesi Utara dan Samudera Pasifik.

Menurut Mertha et al. (2006) ada dua jenis perlkanan Tuna yaitu Tuna industri dan artisanal. Eksploitasi Tuna skala industri terutama menggunakan alat tangkap Tuna long line untuk menangkap Ikan-Ikan Tuna besar pada kedalaman di atas dan di bawah lapisan thermoklin (100 sampai dengan 300 meter). Tuna long line berkembang di Zona Ekonomi Eklusif Indonesia (ZEEI) Samudera Hindia sejak tahun 1972, sejak didirlkan PT (Persero) Perlkanan Samodra Besar (Mertha et al. 2006). Untuk menangkap Tuna besar selain dengan Tuna long line digunakan juga alat tangkap pancing ulur, yang beroperasi di sekitar rumpon laut dalam. Di kawasan timur Indonesia alat ini berkembang di beberapa daerah antara lain, Sulawesi Utara, Teluk Tomini, Laut Maluku dan Selat Makassar. Sejak mulai beroperasi perusahaan pukat cincin joint venture di Sulawesi Utara, berkembang alat tangkap pancing ulur tipe Filipina yang disebut pumpboat. Alat ini menggunakan jukung motor yang besar yang dapat beroperasi sampai dengan 2 minggu atau lebih.

Penyebaran Ikan Cakalang di Indonesia meliputi Samudera Indonesia, pantai barat Sumatera, Selatan Jawa, Bali, Nusa Tenggara, perairan Indonesia Timur meliputi Laut Banda, Laut Flores, Laut Maluku, Laut Makassar (Uktolseja, 1989). Penentuan lokasi penangkapan Ikan Cakalang ditentukan oleh musim berbeda untuk setiap perairan. Penangkapan Ikan Cakalang dapat dilakukan sepanjang tahun. Hasil yang diperoleh berbeda dari musim ke musim bervariasi pula menurut lokasi penangkapan. Saat-saat dengan hasil lebih banyak dari biasanya disebut musim puncak dan bila penangkapan lebih sedikit dari biasanya disebut musim paceklik. Menurut Supriana et al. (2014) daerah penyebaran Ikan Tuna dan Cakalang di Indonesia meliputi Laut Banda, Laut Maluku, Laut Flores, Laut Sulawesi, Laut Hindia, Laut Halmahera, perairan utara Aceh, barat Sumatera, selatan Jawa, utara Sulawesi, Teluk Tomini, Teluk Cendrawasih, dan Laut Arafura. Daerah produksi utama Ikan ini terdapat di Kawasan Indonesia

Tabel 1. Jenis Ikan Tuna dan Cakalang di Indonesia.

\begin{tabular}{cclll}
\hline Jenis & No & \multicolumn{1}{c}{ Nama Lokal } & \multicolumn{1}{c}{ Nama Inggris } & \multicolumn{1}{c}{ Nama IImiah } \\
\hline \multirow{4}{*}{ Tuna } & 1 & Tuna mata besar & Big eye tuna & Thunnus obesus \\
& 2 & Madidihang & Yellow fin tuna & Thunnus albacores \\
& 3 & Albakora & Albacore & Thunnus alalunga \\
& 4 & Cakalang & Skipjack tuna & Katsuwonus pelamis \\
& 5 & Tuna sirip biru selatan & Southern bluefin tuna & Thunnus maccoyii \\
\hline
\end{tabular}

Sumber: KKP (2015). 
Timur yang mencakup Laut Banda, Laut Maluku, Laut Sulawesi, Laut Halmahera, Teluk Cendrawasih dan Laut Arafura, Bitung, Ternate, Ambon dan Sorong merupakan wilayah basis pengembangan untuk mendukung produksi Ikan Tuna dan Cakalang di Kawasan Indonesia Timur tersebut. Provinsi Sulawesi Utara tepatnya di Kota Bitung merupakan wilayah basis pengembangan perlkanan Tuna dan Cakalang terbesar dari beberapa wilayah basis pengembangan yang ada di Kawasan Indonesia Timur. Lokasi Kota Bitung sangat strategis terletak di antara dua wilayah pengelolaan perlkanan yaitu perairan Laut Maluku (WPP-715) dan perairan Laut Sulawesi (WPP-716). Kota Bitung memiliki Pelabuhan Perlkanan Samudera (PPS) yang ditetapkan oleh Peraturan Menteri KP No. PER.19/MEN/2008.

Indonesia saat ini memiliki 5 (lima) pelabuhan perlkanan yang menjadi contoh nasional dalam industrialisasi Tuna, Tongkol dan Cakalang. Selain Kota Bitung sebagai sentra perlkanan Tuna dan Cakalang untuk Kawasan Indonesia Timur, maka untuk Kawasan Indonesia Barat untuk sentra perlkanan Tuna dan Cakalang salah satu yang terbesar adalah di Kabupaten Malang. Potensi Tuna, Tongkol dan Cakalang di Kabupaten Malang pada tahun 2012 mencapai 3787 ton (Dinas Kelautan dan Perinan Provinsi Jawa Timur 2013). Tingginya produksi Kabupaten Malang didukung dengan adanya keberadaan Pelabuhan Perlkanan Pantai (PPP) Pondokdadap.
Secara umum menurut Rumbewas et al. (2011) kegiatan perlkanan Tuna dan Cakalang di Indonesia terbagi atas dua kelompok besar yakni perlkanan Tuna skala besar (industri dan perlkanan kecil (tradisional). Perlkanan Tuna skala besar banyak dilakukan di wilayah Samudera Hindia sebelah Barat Sumatera yang terkonsentrasi di Padang, Banda Aceh dan sebagian di Selatan Jawa yang terpusat di Pelabuhan Ratu-Sukabumi, Cilacap, PrigiTrenggalek, Sendang Biru-Malang dan BenoaBali. Perlkanan Tuna skala kecil banyak dilakukan oleh nelayan Pondokdadap di Sendang Biru Malang, perairan Selat Makassar oleh Nelayan Majene, perairan Sulawesi Tenggara oleh nelayan dari buton dan perairan Utara Sulawesi oleh nelayan Lembeh Kota Bitung. Produksi Ikan Tuna dan Cakalang pada sentra utama di Indonesia ditampilkan pada Tabel 2.

\section{Perkembangan Produksi Tuna dan Cakalang di Indonesia}

Potensi perlkanan Tuna di wilayah perairan Samudera Hindia (barat Sumatera) menurut Uktolseja (1987) yang terdiri dari beberapa jenis antara lain : madidihang, Tuna mata besar dan albakor adalah sebesar 43.000 ton per tahun, namun tingkat pemanfaatannya baru mencapai 19,2\% (Nikijuluw, 2002). Potensi Cakalang (Katsuwonus pelamis) di wilayah perairan barat Sumatera adalah sebesar 64.000 ton per tahun dan baru dimanfaatkan sebesar $14.6 \%$ (Aziz et al., 1998). Produksi Tuna dan Cakalang

Tabel 2. Produksi Ikan Tuna dan Cakalang di Indonesia Pada Sentra Utama Perikanan Menurut Provinsi, Tahun 2015.

\begin{tabular}{clc}
\hline No & \multicolumn{1}{c}{ Provinsi } & Volume Produksi (Ton) \\
\hline 1 & Sumatera Barat & 67.645 \\
2 & Jawa Timur & 42.692 \\
3 & Kepulauan Riau & 30.950 \\
4 & DKI Jakarta & 99.456 \\
5 & Jawa Barat & 59.087 \\
6 & Bali & 75.492 \\
7 & Kalimantan Barat & 59.725 \\
8 & Sulawesi Utara & 242.562 \\
9 & Sulawesi Tengah & 100.564 \\
10 & Maluku & 178.242 \\
11 & Maluku Utara & 114.456 \\
\hline
\end{tabular}

Sumber: Statistik Perikanan Tangkap Indonesia (2015). 
di Provinsi Sumatera Barat selama kurun waktu 10 tahun, yaitu dari tahun 1996-2005 adalah sebesar $131.650,5$ ton.

Sedikit berbeda dengan penangkapan Ikan-Ikan kecil pada umumnya, dalam penangkapan Ikan Tuna dan Cakalang dibutuhkan alat-alat tangkap yang lebih spesifik. Hal ini dikarenakan Ikan Tuna memiliki ukuran tubuh yang besar dan perlakuan yang khusus dalam proses penangkapannya. Karakteristik alat tangkap Tuna sangat bergantung pada armada yang digunakan, yang dapat digolongkan menjadi armada yang modern dan tradisional. Umumnya armada penangkapan modern menggunakan alat tangkap berupa pancing longline, sedangkan tradisional berupa pancing ulur, pancing layang-layang, ataupun pancing hanyut.

Produksi tangkap Ikan Tuna dan Cakalang di Indonesia secara keseluruhan terus meningkat sejak tahun 2000 sampai dengan tahun 2015. Jumlah produksi Ikan Cakalang lebih besar jika dibandingkan dengan produksi Ikan Tuna. Peningkatan produksi Ikan Tuna dan Cakalang menunjukkan bahwa tingginya tingkat permintaan terhadap kedua komoditas perlkanan tersebut. Meskipun jumlah produksi Ikan Tuna lebih kecil dibandingkan dengan Ikan Cakalang namun untuk nilai produksinya memiliki nilai yang lebih tinggi.
Hal ini menunjukkan bahwa harga satuan Ikan Tuna memiliki nilai yang lebih besar. Untuk harga satuan Ikan Tuna rata-rata dalam kurun waktu tahun 2000 2016 adalah sebesar Rp14.260.000/ton dan untuk Ikan Cakalang sebesar Rp8.889.000/ ton. Secara agregat nilai komoditas Ikan Tuna dan Cakalang terus mengalami peningkatan setiap tahunnya. Peningkatan signiflkan terjadi pada kurun waktu 3 (tiga) tahun terakhir yang mencapai kisaran 40\%. Grafik harga komoditas Ikan Tuna dan Cakalang dalam kurun waktu tahun 2000 - 2015 ditampilkan pada Gambar 1.

Alat tangkap yang digunakan oleh nelayan di Indonesia untuk menangkap Ikan Tuna dan Cakalang sangat beragam. Berdasarkan data statistik perlkanan tangkap terdapat 6 jenis kelompok alat tangkap yang digunakan untuk menangkap Ikan Tuna dan Cakalang antara lain adalah rawai Tuna (Tuna long line), rawai hanyut selain rawai Tuna (drift longline othe than Tuna long line), rawai tetap (set long line), huhate (skipjack pole and line), pancing tonda (troll line) dan pancing yang lain (other pole and line) termasuk didalamnya adalah pancing ulur (handline) yang biasa digunakan oleh nelayan tradisional untuk menangkap Ikan Tuna dan Cakalang. Perusahaan penangkapan Ikan Tuna dan Cakalang skala besar pada umumnya juga menggunakan alat tangkap pukat cincin (purse seine) namun, penelitian ini alat tangkap tersebut tidak dimasukkan kedalam

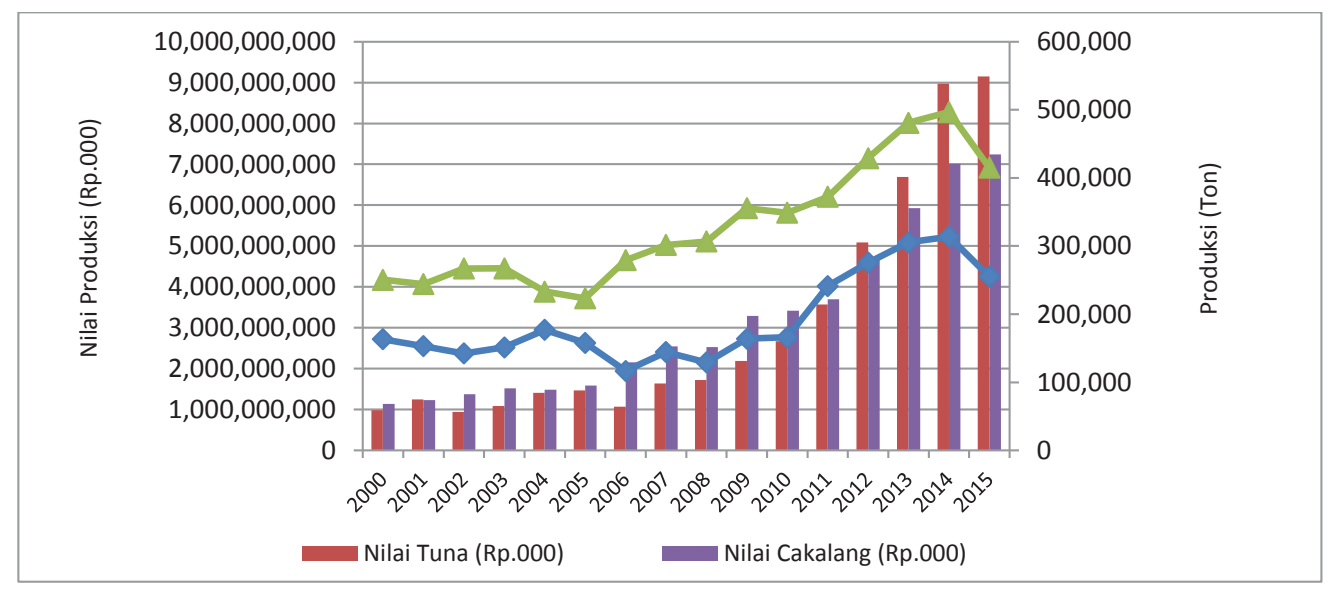

Gambar 1. Produksi Tangkap (Ton) dan Nilai Produksi (Rp.000) Ikan Tuna dan Cakalang di Indonesia Selama Kurun Waktu 2000 - 2015 
analisis karena dalam data statistik tidak dapat dibedakan penggunaan alat tangkap pukat cincin (purse seine) yang digunakan oleh armada penangkapan untuk menangkap Ikan Tuna dan Cakalang dan bukan untuk menangkap Ikan Tuna dan Cakalang seperti Ikan tenggiri, Ikan Tongkol, Ikan tembang dan jenis Ikan pelagis lainnya.

Secara teknis penggunaan alat tangkap yang telah disebutkan di atas tidak spesifik hanya untuk menangkap Ikan Tuna atau Cakalang saja, namun ada juga jenis Ikan lainnya yang dapat tertangkap oleh alat tangkap tersebut atau biasa dikenal dengan istilah tangkapan sampingan (by catch). Hasil penelitian yang dilakukan oleh Kurniawan et al. (2014) menunjukkan bahwa alat tangkap yang digunakan oleh nelayan (pancing dan jaring insang) untuk menangkap Ikan Cakalang, Tuna, Tongkol dan tenggiri ternyata juga mendapat hasil tangkapan sampingan seperti Ikan hiu dan jenis Ikan karang. Nugraha dan Setyadji (2013) juga menunjukkan hasil yang sama bahwa alat tangkap rawai Tuna (Tuna longline) tidak semua hasil tangkapan yang diperoleh adalah Ikan target utama (Ikan Tuna) namun ada sebagian besar adalah jenis Ikan lainnya seperti Ikan pari, Ikan naga dan Ikan layar. Penggunaan alat tangkap dengan target utama Ikan tangkapan Tuna seperti rawai Tuna dan pancing ulur Tuna tidak selalu mendapatkan Ikan hasil tangkapan target utama. Penggunaan alat tangkap tersebut bisa saja menangkap Ikan pelagis besar lainnya seperti Ikan Cakalang. Begitupun penggunaan alat tangkap huhate yang lebih banyak digunakan oleh nelayan di Indonesia untuk menangkap Ikan Cakalang namun bisa juga digunakan untuk menangkap Ikan Tuna (baby Tuna). Berdasarkan hal tersebut diasumslkan dan dibatasi bahwa penggunaan alat tangkap rawai Tuna, rawai hanyut selain rawai Tuna, rawai tetap, huhate, pancing tonda dan pancing ulur merupakan alat tangkap yang dapat digunakan untuk menangkap jenis Ikan Tuna dan Cakalang. Pada Tabel 3 dapat dilihat informasi terkait jenis dan jumlah alat tangkap penangkapan Ikan Tuna di Indonesia.

Penggunaan alat tangkap jenis pancing tonda merupakan yang terbanyak. Pancing merupakan alat tangkap yang memiliki tingkat selektivitas tinggi dan ramah lingkungan (Hariyanto et al., 2008). Pada klasifikasi jenis alat tangkap "pancing yang lain" diantaranya termasuk pancing ulur. Alat tangkap pancing ulur merupakan jenis alat tangkap yang paling banyak digunakan oleh nelayan tradisional Tuna yang ada di Indonesia seperti di Kabupaten Malang dan Kota Bitung (Firdaus dan Witomo 2014; Ramadhan et al., 2014).

Tabel 3. Jenis dan Jumlah Alat Tangkap (unit) Penangkapan Ikan Tuna dan Cakalang di Indonesia Dalam Kurun Waktu Tahun 2000 - 2015.

\begin{tabular}{ccccc}
\hline Tahun & Rawai Tuna & Huhate & Pancing tonda & \multicolumn{1}{c}{ Total } \\
\hline 2000 & 2.870 & 1.581 & 60.160 & 64.611 \\
2001 & 3.821 & 1.951 & 66.364 & 72.136 \\
2002 & 2.264 & 2.092 & 53.748 & 58.104 \\
2003 & 6.547 & 2.512 & 66.255 & 75.314 \\
2004 & 5.656 & 5.032 & 93.523 & 104.211 \\
2005 & 5.226 & 3.872 & 101.525 & 110.623 \\
2006 & 9.290 & 6.861 & 98.966 & 115.117 \\
2007 & 8.993 & 15.765 & 83.514 & 108.272 \\
2008 & 10.239 & 16.486 & 87.011 & 113.736 \\
2009 & 10.345 & 12.727 & 84.953 & 108.025 \\
2010 & 8.558 & 7.379 & 64.554 & 80.491 \\
2011 & 10.125 & 8.167 & 82.754 & 101.046 \\
2012 & 12.714 & 7.338 & 86.523 & 106.575 \\
2013 & 11.235 & 4.263 & 88.328 & 103.826 \\
2014 & 8.403 & 3.932 & 78.925 & 91.260 \\
2015 & 6.473 & 1.772 & 76.994 & 85.239 \\
\hline
\end{tabular}

Sumber: Statistik Perikanan Tangkap, 2016. 


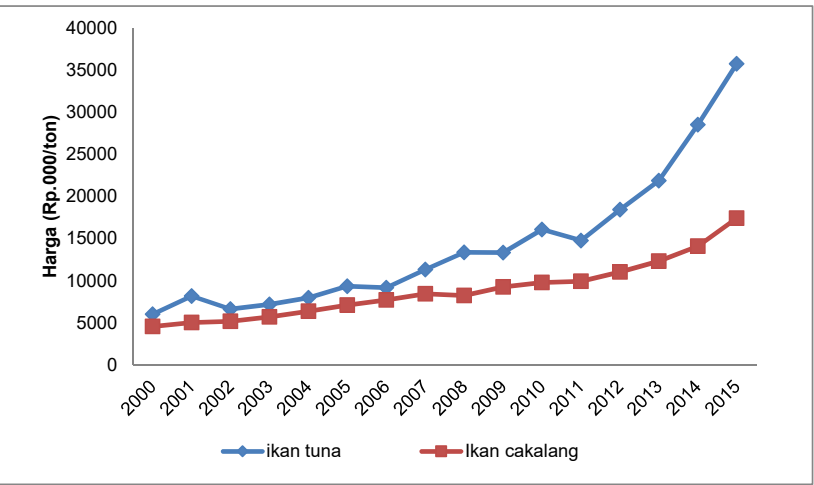

Gambar 2. Grafik Harga Ikan Tuna dan Cakalang (Rp.000/ton) di Indonesia dalam Kurun Waktu Tahun 2000 - 2015.

Produktivitas tertinggi dari penggunaan alat tangkap adalah jenis alat tangkap rawai Tuna, hal ini dikarenakan dalam satu unit alat tangkap rawai Tuna terdapat mata pancing yang sangat banyak. Mata pancing tersebut bisa mencapai lebih dari 1000 mata pancing. Jumlah ini tentu jauh lebih besar dari jumlah mata pancing huhate, pancing ulur dan pancing tonda yang semuanya bersifat tunggal mata pancing (single bait)

Jika dikaitkan antara jumlah unit alat tangkap dengan jumlah hasil tangkapan, diketahui bahwa setiap kenalkan jumlah alat tangkap dalam suatu periode belum tentu berdampak terhadap peningkatan hasil tangkapan Ikan Tuna dan Cakalang (Gambar 2). Hal ini menunjukkan bahwa besarnya jumlah produksi tangkapan Ikan Tuna dan Cakalang tidak hanya dipengaruhi oleh jumlah alat tangkap tetapi terdapat faktor lainnya seperti penggunaan armada penangkapan, sifat musiman penangkapan dan jumlah pelaku penangkapan. Faktor illegal, unreported and unregulated fishing (IUU Fishing) diduga menjadi salah satu penyebab pelaporan secara statistik jumlah produksi Tuna dan Cakalang tidak signiflkan dengan kenalkan jumlah alat tangkap yang digunakan. Hasil produksi yang tidak terlaporkan atau tidak tercatat dari komoditas Tuna dan Cakalang memberlkan dampak secara statistik nilai produksi Tuna dan Cakalang di Indonesia tidak sesuai. Hal ini mungkin saja terjadi mengingat Ikan Tuna dan Cakalang merupakan komoditas ekspor unggulan. Hasil penelitian yang dilakukan oleh Wijaya et al. (2012) menunjukkan adanya indikasi perdagangan Ikan Tuna dan Cakalang yang dilakukan di tengah laut di perairan Indonesia untuk dijual langsung ke negara Filipina sehingga produksi tangkapannya tidak tercatat pada pelabuhan base kapal penangkapan tersebut yang berada di Indonesia. Hal ini pun sejalan dengan hasil penelitian Syahrani et al. (2017) yang mengungkapkan bahwa komoditas Ikan Tuna rentan untuk dilakukan praktek IUU fishing khususnya unreported terhadap hasil tangkapan.

Pada Gambar 3 terlihat bahwa jumlah produksi Ikan Tuna dan Cakalang terbesar pada tahun 2014 yaitu sebesar 810.555 ton dan untuk jumlah unit alat tangkap terbesar pada tahun 2008 yaitu sebesar 113.736 unit. Jumlah produksi dan alat tangkap penangkap Ikan Tuna dan Cakalang di Indonesia mengalami fluktuatif. Jenis alat tangkap yang digunakan di dominasi oleh alat tangkap yang bersifat tradisional (pancing ulur/handline). Hal ini menunjukkan bahwa secara keseluruhan perlkanan Tuna dan Cakalang di Indonesia di dominasi oleh penangkapan dengan skala usaha yang kecil. Meskipun secara produktivitas hasil penangkapan oleh nelayan atau perusahaan penangkapan skala besar sangat tinggi namun jumlah pelaku usaha penangkapan yang dilakukan oleh nelayan skala kecil lebih banyak. Menurut Ramadhan et al., (2014), skala pemanfaatan perlkanan secara umum terbagi atas dua bagian, yaitu skala industri dan skala kecil atau tradisional. Perlkanan skala kecil juga seringkali disebut sebagai perlkanan tradisional (Smith, 1983). 


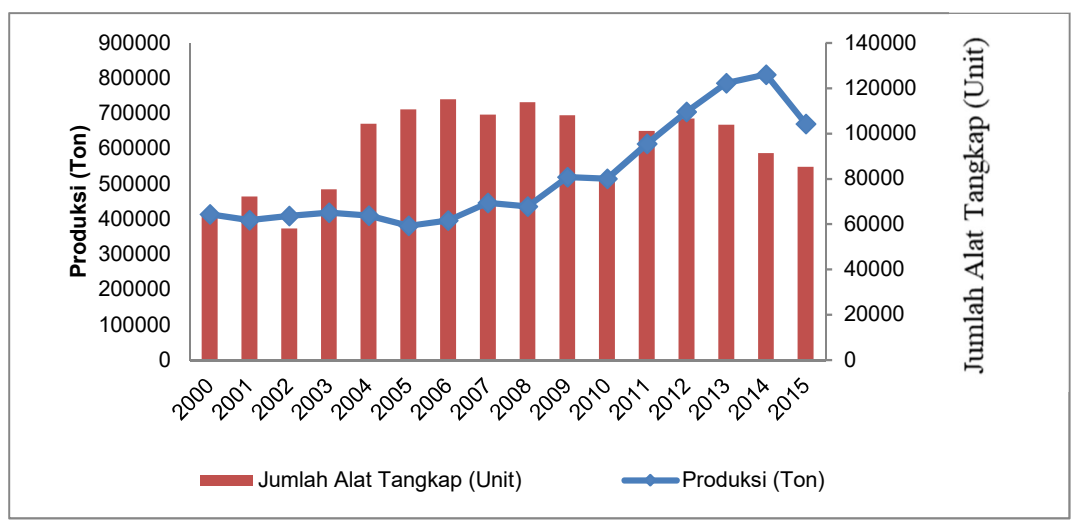

Gambar 3. Jumlah Alat Tangkap (unit) dan Produksi Tangkap (Ton) Ikan Tuna dan Cakalang di Indonesia Dalam Kurun Waktu Tahun 2000 - 2015.

Pada kasus ini jenis kapal yang digolongkan masuk ke dalam skala industri adalah kapal yang berukuran lebih besar dari 30 GT sedangkan skala kecil yang berukuran kurang dari 30 GT. Secara statistik, jumlah kapal dibawah 30 GT merupakan kapal yang dominan yaitu mencapai $91,3 \%$ (KKP 2011).

\section{PENUTUP}

Tuna dan Cakalang adalah jenis Ikan pelagis besar yang pada umumnya beruaya jauh (highly migratory). Ikan ini memiliki nilai ekonomis tinggi yang tersebar hampir diseluruh wilayah perairan Indonesia. Perlkanan Tuna dan Cakalang di Indonesia terdiri dari dua jenis yaitu industri dan artisanal. Daerah penyebaran Ikan Tuna dan Cakalang di Indonesia meliputi Laut Banda, Laut Maluku, Laut Flores, Laut Sulawesi, Laut Hindia, Laut Halmahera, perairan utara Aceh, barat Sumatera, selatan Jawa, utara Sulawesi, Teluk Tomini, Teluk Cendrawasih, dan Laut Arafura. Produksi tangkap Ikan Tuna dan Cakalang di Indonesia secara keseluruhan terus meningkat sejak tahun 2000 sampai dengan tahun 2015. Peningkatan produksi Ikan Tuna dan Cakalang menunjukkan bahwa tingginya tingkat permintaan terhadap kedua komoditas perlkanan tersebut.

Alat tangkap yang digunakan oleh nelayan di Indonesia untuk menangkap Ikan Tuna dan Cakalang sangat beragam. Berdasarkan data statistik perlkanan tangkap terdapat 6 jenis kelompok alat tangkap yang digunakan untuk menangkap Ikan Tuna dan Cakalang antara lain adalah rawai Tuna (Tuna long line), rawai hanyut selain rawai Tuna (drift longline othe than Tuna long line), rawai tetap (set long line), huhate (skipjack pole and line), pancing tonda (troll line) dan pancing yang lain (other pole and line) termasuk didalamnya adalah pancing ulur (handline) yang biasa digunakan oleh nelayan tradisional untuk menangkap Ikan Tuna dan Cakalang. Hasil kajian menunjukkan bahwa kenalkan jumlah alat tangkap dalam suatu periode belum tentu berdampak terhadap peningkatan hasil tangkapan Ikan Tuna dan Cakalang. Hal ini menunjukkan bahwa besarnya jumlah produksi tangkapan Ikan Tuna dan Cakalang tidak hanya dipengaruhi oleh jumlah alat tangkap tetapi terdapat faktor lainnya seperti penggunaan armada penangkapan, sifat musiman penangkapan dan jumlah pelaku penangkapan. Faktor illegal, unreported and unregulated fishing (IUU Fishing) diduga menjadi salah satu penyebab pelaporan secara statistik jumlah produksi Tuna dan Cakalang tidak signiflkan dengan kenalkan jumlah alat tangkap yang digunakan.

\section{UCAPAN TERIMA KASIH}

Penulis mengucapkan terima kasih kepada Saudari Hertria Maharani Putri yang telah banyak membantu penulis dalam mengumpulkan laporan statistik terkait Tuna dan Cakalang. Ucapan terima kasih juga kami sampalkan kepada segenap tim redaksi yang telah memberlkan masukan dan arahan untuk penyempurnaan tulisan ini. 


\section{DAFTAR PUSTAKA}

Aziz, K.A., M. Boer, J. Widodo, N. Naamin, M.H. Amarullah, B. Hasyim, A. Djamali, B.E Priyono. 1998. Potensi, Pemanfaatan dan Peluang Pengembangan Sumber daya Ikan Laut di Perairan Indonesia. Komisi Nasional Pengkajian Sumber daya Perlkanan Laut. PKSPL. IPB. Bogor.

Badan Perencanaan Pembangunan Nasional. 2014. Pembangunan Kelautan dalam RPJMN 2015-2019. Rapat Koordinasi Kementerian Kelautan dan Perlkanan, Tema : RKP 2015 dan RPJMN 2015-2019. Bappenas. Jakarta.

Fauzi, A. dan Z. Anna. 2002. Penilaian Depresiasi Sumber daya Perlkanan Sebagai Bahan Pertimbangan Penentuan Kebijakan Pembangunan Perlkanan. Jurnal Pesisir dan Lautan. Volume 4, No 2, 2002 : 36 - 49 Bogor : Pusat Kajian Sumber daya Pesisir dan Lautan. Institut Pertanian Bogor. Bogor.

Fauzi, A. 2010. Ekonomi Perlkanan "Teori, Kebijakan dan Pengelolaan". PT Gramedia Pustaka Utama. Jakarta

Firdaus, M. dan C.M Witomo. 2014. Analisis Tingkat Kesejahteraan dan Ketimpangan Pendapatan Rumah Tangga Nelayan Pelagis Besar di Sendang Biru, Kabupaten Malang, Jawa Timur. Jurnal Sosial Ekonomi Kelautan dan Perlkanan Vol 9 No 2 (2014). Pusat Penelitian Sosial Ekonomi Kelautan dan Perlkanan. Jakarta.

Hariyanto, T., M.S Baskoro, J. Haluan dan B.H Iskandar. 2008. Pengembangan Teknologi Penangkapan Ikan Brbasis Komoditas Potensial Di Teluk Lampung. Jurnal Saintek Perlkanan. Vol. 4: 16 -24.

Kementerian Kelautan dan Perlkanan. 2006. Statistik Perlkanan Tangkap 2006. Direktorat Jenderal Perlkanan Tangkap. KKP. Jakarta.

2007 Statistik Perlkanan Tangkap 2007. Direktorat Jenderal Perlkanan Tangkap. KKP. Jakarta.

2008. Statistik Perlkanan Tangkap 2008. Direktorat Jenderal Perlkanan Tangkap. KKP. Jakarta.

2009. Statistik Perlkanan Tangkap 2009. Direktorat Jenderal Perlkanan Tangkap. KKP. Jakarta.

2010. Statistik Perlkanan Tangkap 2010. Direktorat Jenderal Perlkanan Tangkap. KKP. Jakarta.
2011. Statistik Perlkanan Tangkap 2011. Direktorat Jenderal Perlkanan Tangkap. KKP. Jakarta.

2012 Statistik Perlkanan Tangkap 2012. Direktorat Jenderal Perlkanan Tangkap. KKP. Jakarta.

2013. Statistik Perlkanan Tangkap 2013. Direktorat Jenderal Perlkanan Tangkap. KKP. Jakarta.

. 2014. Statistik Perlkanan Tangkap 2014. Direktorat Jenderal Perlkanan Tangkap. KKP. Jakarta.

. 2015. Rencana Pengelolaan Perlkanan Tuna, Cakalang dan Tongkol. Direktorat Sumber daya Ikan Direktorat Jenderal Perlkanan Tangkap. KKP. Jakarta.

Kurniawan, A., M. Fajar, I. Apriliazm dan A. Nugraha. 2014. Identifikasi Status Konservasi Hiu Tangkapan Samping di Pelabuhan Perlkanan Nusantara Pulau Bangka dan Belitung. Prosiding Simposium Pengelolaan Perlkanan Tuna Berkelanjutan 2014. WWF - KKP. Bali.

Mertha I.G.S, M. Nurhuda, dan A. Nasrullah. Perkembangan Perlkanan Tuna di pelabuhan ratu. Jurnal Penelitian Perlkanan Indonesia Vol 12 No 2 Agustus 2006. 117-127. Balitbang kelautan dan perlkanan. KKP. Jakarta.

Nikijuluw, V.P.H. 2002. Rezim Pengelolaan Sumber Daya Perlkanan. PT. Pustaka Cidesindo. Jakarta

Nugraha, B., dan B. Setyadji. 2013. Kebijakan Pengelolaan Hasil Tangkapan Sampingan Tuna Longline di Samudera Hindia. Jurnal Kebijakan Perlkanan Indonesia. Vol 5 No/ 2 (2013). Pusat Penelitian dan Pengembangan Perlkanan. Jakarta

Ramadhan, A., M. Firdaus, dan R.A Wijaya. 2014. Analisis Nilai Tukar Nelayan (NTN) Pelagis Besar Tradisional. Jurnal Sosial Ekonomi Kelautan dan Perlkanan Vol 9 No I (2014). Pusat Penelitian Sosial Ekonomi Kelautan dan Perlkanan. Jakarta.

Rumbewas, F., J.A Andaki, C.R. Dien. 2015. Karakteristik Buruh Wanita Pengangkut Ikan di Tempat Pelelangan Ikan (TPI) Tumumpa Kota Manado. Akulturasi Jurnal IImiah Agrobisnis Perlkanan Vol III No 5 (2015). Universitas Sam Ratulangi. Manado

Samosir, A. 2014. Sektor Perlkanan : PNBP YANG TERABAlkan. https: //www.kemenkeu.go.id/ sites/default/files/sektor_perlkanan_060314. pdf. Diakses pada 8 Oktober 2018. 
Sibagariang, O.P, Fauziyah, dan F. Agustriani. Analisis Potensi Lestari Sumber daya Perlkanan Tuna Longline di Kabupaten Cilacap, Jawa Tengah. Maspari Journal vol 03 (2011) 24-29. PS IImu Kelautan FMIPA UNSRI. Riau

Smith, G.P. 1983. Quantitative Plant Ecology.Blackwell Scientific Publications. Oxford.

Supriana, A.B. Hascaryo, S.H. Wisudo, M. Baskoro, dan V.P.H Nikijuluw. 2014. Model Rantai Nilai Pengembangan Perlkanan Tuna, Tongkol dan Cakalang di Indonesia. Jurnal Pengolahan Hasil Perlkanan Indonesia Volume 17 Nomor 2. Institut Pertanian Bogor. Bogor

Syahrani D.A, M.A. Musadieq, danA. Darmawan. 2017. Analisis Peran Kebijakan Illegar, Unreported and Unregulated Fishing (IUU) Pada Ekspor Ikan Tuna dan Udang Tangkap (Studi pada sebelum dan sesudah penerapan Permen KP nomor 56 dan 57/ PERMEN KP 2014 terhadap Volume Ekspor Tuna dan Udang Tangkap di Jawa Timur). Jurnal Administrasi Bisnis (JAB) Vol 45 No 1 (2017). Fakultas Administrasi dan Bisnis. Universitas Brawijaya. Malang.

Uktolseja, J.C.B. 1987. Estimated Growth Parameters and Migration of Skipjack Tuna -Katsuwonus pelamis In The Eastern Indonesian Water Through Tagging Experiments. Jakarta : Jurnal Penelitian Perlkanan Laut No. 43 Tahun 1987. Balai Penelitian Perlkanan Laut. Hal. 15-44. Jakarta.

Wijaya R.A, H.M. Huda, dan Manadiyanto. 2012. Penguasaan Aset dan Struktur Pembiayaan Usaha Penangkapan Ikan Tuna Menurut Musim Yang Berbeda. Jurnal Sosial Ekonomi Kelautan dan Perlkanan Vol 7 No 2 (2012). Pusat Penelitian Sosial Ekonomi Kelautan dan Perlkanan. Jakarta. 